\title{
POST-TRAUMATIC STRESS DISORDER AND EXPOSURE TO VIOLENCE AMONG VENDA
} AND NORTHERN SOTHO ADOLESCENTS

\section{KGF Esterhuyse}

$\mathrm{PhD}$

Professor, Department of Psychology, University of the Free State

\section{DA Louw}

$\mathrm{PhD}, \mathrm{PhD}$

Head of Department, Department of Psychology, University of the Free State

Corresponding author: louwda.hum@ufs.ac.za

\author{
JM Bach \\ MA \\ Research assistant and student, Department of Psychology, University of the Free State
}

Keywords: post-traumatic stress disorder (PTSD); violence; cross-cultural; adolescent; South Africa

\begin{abstract}
In this study, two research questions were posed. In the first place, this study investigated the levels of exposure to violence among the adolescents as a total group (Venda- and Northern Sotho-speaking), as well as the exposure levels of the two ethnic groups. The relationship between the groups' exposure to violence and their post-traumatic stress disorder (PTSD) symptoms was investigated in the second place, as well as the question whether a difference existed between the two ethnic groups in respect of this relationship. The participants were comprised of 186 Venda and 151 Northern Sotho adolescents, who completed the Child PTSD Checklist (PTSDC) and the Child Exposure to Violence Form (CEVF). A large proportion of participants reported high levels of exposure to violence. Venda youth appeared to be subjected to a higher rate of victimisation than the Northern Sotho adolescents. $A$ strong correlation was found between exposure to violence and PTSD symptoms.
\end{abstract}

\section{OPSOMMING}

Twee navorsingsvrae is in hierdie studie gestel. Eerstens het hierdie studie ondersoek ingestel na die vlakke van blootstelling aan geweld onder die groep adolessente as geheel (Venda- en Noord-Sotho-sprekers), asook na die blootstellingsvlakke van die twee etniese groepe. Tweedens is die verband tussen die groepe se blootstelling aan geweld en hulle simptome van posttraumatiese stresversteuring (PTSV) ondersoek, asook die vraag of daar ' $n$ verskil was tussen die twee etniese groepe ten opsigte van hierdie verband. Die deelnemers het bestaan uit 186 Venda- en 151 Noord-Sotho-adolessente, wat die Child PTSD Checklist (PTSDC) en die Child Exposure to Violence Form (CEVF) voltooi het. ' $n$ Groot gedeelte van die deelnemers het hoë vlakke van blootstelling aan geweld aangedui. Dit het geblyk dat Venda-jeugdiges aan 'n hoër koers van viktimisering blootgestel is as die Noord-Sotho-adolessente. ' $n$ Sterk korrelasie is gevind tussen blootstelling aan geweld en PTSV-simptome. 


\section{INTRODUCTION}

An alarming number of children worldwide are exposed to extreme stressors that can have detrimental effects on their psychological well-being. Numerous authors, such as Baker (1991:243), Chih-Hao and Jing-Houng (1997:243) and Poelmans (2001), have pointed out that a strong correlation exists between stressors and mental health problems. In a significant number of cases, a severe stressor can predispose children and adolescents to the development of post-traumatic stress disorder (PTSD) (Giaconia, Reinherz, Silverman, Pakiz, Frost \& Cohen, 1995:1369; Shannon, Lonigan, Finch \& Taylor, 1994:80). This disorder occurs in individuals who have been exposed to a traumatic event, and is characterised by the persistent re-experiencing of the specific event, avoidance of stimuli associated with the trauma, and increased arousal in the form of symptoms such as irritability, concentration problems and an exaggerated startle response (American Psychiatric Association, 2000).

Exposure to violence - which is widespread in South Africa - is a major precursor of PTSD, with the result that South Africa is viewed as one of the most stressful societies in the world (compare Masuku, 2002:5). Such conditions have led to a relatively high prevalence of PTSD among the South African youth. Figures quoted in this regard vary between $5 \%$ and $22 \%$ (Blignaut, 1996; Ensink, Robertson, Zissis \& Leger, 1997:1526; Peltzer, 1999; Seedat, Van Noord, Vythilingum, Stein \& Kaminer, 2000:38; Seedat, Nyamai, Njenga, Vythilingum \& Stein, 2004:169). The corresponding international figures usually range from $2 \%$ to $6 \%$ (Giaconia et al. 1995:1369). Several studies show that PTSD is a significant problem of public health in South Africa, affecting all individuals in society - from adults to children (Edwards, 2005:191). The present study was undertaken to investigate the extent to which high school children in the Limpopo Province, South Africa, were exposed to traumatic events and reported symptoms characteristic of PTSD.

\section{Exposure to violence and PTSD}

Children not only develop PTSD after exposure to traumas such as accidents and natural disasters, but also in response to exposure to violence in the form of war, violent crime in the community and physical or sexual abuse. Studies have found exposure to violence to be a strong predictor of PTSD in young victims and witnesses of violent events, as well as those who have heard about such events (Duckworth, Hale, Clair \& Adams, 2000:820; Mazza \& Reynolds, 1999:209; Singer, Anglin, Song \& Lunghofer, 1995:477; Slovak \& Singer, 2001:52). When compared with other environmental stressors such as neighbourhood poverty and discrimination, exposure to violence exhibited the strongest correlation with PTSD symptoms (Myers \& Thompson, 2000:264).

Research comparing the psychological distress experienced by victims and witnesses of violent events has yielded contradictory findings. In some studies, witnesses and victims have been found to exhibit similar stress reactions (Fitzpatrick \& Boldizar, 1993:424; Saigh, 1991:213). The results of a study by Litrownik, Newton, Hunter, English and Everson (2003:71), suggest that even though there was a relationship between witnessed and directly experienced family violence, both had independent, non-interactive effects on subsequent behavior problems. In a study by Fitzpatrick (1993:528), victims of violence reported more depressive symptoms than witnesses. Duckworth et al. (2000:814) found that direct victimisation had a stronger correlation to behavioural problems than witnessing violence.

In the light of the limited and conflicting evidence, it is uncertain at this stage whether victims and witnesses of violence differ in respect of their psychological PTSD symptoms after exposure to violence. There are also conflicting findings with regard to the psychological consequences for people who have had combined experiences of being both witnesses to violence and victims thereof. For example, Pelcovitz, Kaplan, De Rose, Mandel and Salzinger (2001:360) found a difference between children who had been abused, and those who had been abused but who had also been witnesses to inter-parental violence. Those experiencing both forms of exposure had a higher risk of developing psychological disorders such as depression and PTSD than those who were victims of abuse only. However, Saigh (1991:213) compared the distress of those who had been both witnesses to and victims of a violent event to the distress of those who had either been witnesses or victims, and found no differences in psychological sequelae. 
There is evidence that exposure to high frequencies of violence, such as chronic community violence, triggers more adverse psychological responses than exposure to low frequencies of violence, suggesting a cumulative effect on the distress experienced. For example, CooleyQuille, Turner and Beidel (1995:1362) investigated the emotional and behavioural consequences of high and low exposure to violence. More symptoms of anxiety, fear, internalising behaviour and negative life experiences were found for those exposed to high levels of violence than for those with low exposure. However, a later study (Cooley-Quille, Boyd, Frantz \& Walsch, 2001:199) failed to find any effect with regard to different frequencies of exposure on the prevalence of DSM-III-R diagnoses.

Several researchers have attempted to determine which variables may predispose, aggravate or buffer the psychological effects of violent trauma. Certain researchers have found differences in the prevalence levels of PTSD between ethnic groups (Mghir \& Raskin, 1999:29; Shannon et al. 1994:80). It has been suggested that these differences can be attributed, at least in part, to varied exposure to traumatic events. In the United States, for instance, it is reported that minority group males are exposed to higher levels of violence than white males (National Center for Juvenile Justice, 1999). Since higher exposure to violence has been associated with lowerincome urban neighbourhoods, where large minority populations reside in certain cases (Berton \& Stabb, 1996:489), and since exposure to violence increases one's risk of PTSD, it seems likely that such minority groups would exhibit a higher prevalence of PTSD than other, less exposed ethnic groups. Victim surveys done in South Africa show that the poor are more at risk of being victims of interpersonal violent crimes, as well as violent property crimes like robbery (Masuku, 2002:9). Hunt (2003) also relates South Africa's high rate of violent crime to economic and social marginalisation. Not all studies have found differences in the prevalence of PTSD between ethnic groups after exposure to violence (Mazza \& Reynolds, 1999:207; Pynoos, Frederick, Nadar, Arroyo, Eth, Nunez, Steinbert \& Fairbanks; 1987:1057; Singer et al. 1995:477). Nevertheless, some differences between ethnic groups in respect of PTSD and anxiety symptoms have been found - even when variables such as socio-economic standing and exposure to trauma are taken into account (Crouch, Hanson, Saunders, Kilpatrick \& Resnick, 2000:635; Neal \& Turner, 1991:400; Perilla, Norris \& Lavizzo, 2002:20).

\section{AIM OF STUDY}

This study focuses on expanding our knowledge regarding the epidemiology of PTSD among South African adolescents by examining two samples - one Venda-speaking and the other Northern Sotho-speaking. These two ethnic groups were included since virtually no research data exist for them. The aim of the study was twofold: firstly, to determine the level of violence to which the adolescents were exposed; and secondly, to determine the extent to which different forms of exposure to violence were associated with the adolescents' PTSD symptoms. The possible role played by ethnicity in this regard will also be investigated.

\section{METHOD}

\section{Participants and settings}

Data were collected from two secondary schools in the Limpopo Province in South Africa. A total of 337 learners from Grades 9-12 participated in the study. The participants consisted of 186 Venda speakers (92 females and 94 males) and 151 Northern Sotho speakers (78 females and 73 males). Ages ranged from 15 to 19 years. The mean age of the group was 16.78 years, with a standard deviation of 1.09 years. The purpose and rational of the project were explained to the children by the headmasters of the schools involved. Participation was voluntary.

\section{Instruments}

The Children's Exposure to Violence Form (CEVF) (Amaya-Jackson, 1995) assesses participants' exposure to community violence. The form was modified so that the questions were separated into two categories of witnessed and victimisation events. This distinction was made because the persons who had been directly exposed to violence may have been more susceptible to PTSD than those who had only witnessed it (Duckworth et al. 2000:814). Six questions in total were omitted (Questions 3, 10, 12, 13, 22 and 29), and the following two questions were added: Have you ever seen a riot in your neighbourhood? Have you ever participated in a riot in your neighbourhood? The reason for this alteration was that this topic was not covered by the CEVF, and riots had been occurring in the Limpopo province at the time of the study. The number of items 
therefore added up to a total of 30. (The CEVF is comprised of 34.) These items give an indication of the participants' exposure to different acts of violence. The CEVF yields three scores: Violence (Witness), Violence (Victim) and Violence (Total). Fehon, Grilo and Lipschitz (2001:532), using a 1998 version of the form, determined that its psychometric properties were adequate.

The Child PTSD Checklist (Amaya-Jackson, McCarthy, Newman \& Cherney, 1995) consists of 28 items, and is used to determine the nature and intensity of PTSD symptoms in children and adolescents. Participants rate the degree to which the symptoms have been present in the past month on a 4-point Likert scale, ranging from "not at all" (0) to "sometimes"(1), "most of the time"(2) and "all of the time"(3). A symptom was classified as present in respect of participants who responded "most of the time" or "all of the time" to that item. At the end of the checklist, participants are asked an open-ended question requiring them to write down three experiences from their past that they felt were scary or frightening, and to describe their associated feelings. The checklist yields four scores, namely a total PTSDC symptom score as well as three cluster scores based on the DSM-IV criteria for PTSD: Cluster $\mathrm{B}$ (Re-experiencing), Cluster C (Avoidance) and Cluster D (Hyperarousal). A PTSD diagnosis requires that an individual should have at least one symptom in Cluster $\mathrm{B}$, three symptoms or more in Cluster $\mathrm{C}$ and two or more symptoms in Cluster D. However, the PTSDC itself cannot provide a formal diagnosis, since it does not gauge the duration of symptoms or the degree of distress or impairment caused by the symptoms. Lipschitz, Grilo, Fehon, McGlashan and Southwick (2000:351) used a 1998 version of the form, and found that it had acceptable psychometric properties. The psychometric characteristics of the scale for the present population were examined by calculating the following alpha coefficients for the combined sample: PTSDC Total $=0.82$; Cluster B (Re-experiencing $)=0.65$; Cluster $\mathrm{C}($ Avoidance $)=0.60$; Cluster $\mathrm{D}($ Hyperarousal $)=$ 0.50 . The PTSDC Total scale has acceptable reliability, but those for the subscales are rather low. According to Foster and Parker (1995:90) reliability constructs lower than 0.8 . are acceptable concerning non-cognitive measures.

Participants provided data on their age and home lan- guage, and completed the above-mentioned two measuring instruments. The headmasters of both schools confirmed that English was one of the primary languages of instruction. As no Venda or Northern Sotho translations were available, the questionnaires were administered in English, the original language in which they had been compiled.

\section{Procedure}

Approval to conduct the study was granted by the Department of Education. Data were collected on site at the two secondary schools, the largest Venda-speaking secondary school and the largest Northern Sothospeaking secondary school in the Soutpansberg district of the Limpopo Province. The two questionnaires were administered to the learners by the researcher, with the assistance of class teachers. Participants were informed briefly on the purpose of the study, and received guidance on how to fill in the forms correctly. They were also assured that their responses would be kept strictly confidential.

\section{Statistical Analysis}

The aims of the analysis were twofold: firstly, to determine the level of violence to which the adolescents as a group, as well as the different ethnic groups, were exposed; secondly, to investigate the relationship between the group's exposure to violence and their posttraumatic stress disorder (PTSD) symptoms, and to determine whether there were any differences between the two ethnic groups in respect of this relationship. To reach the first aim of the study, the $\mathrm{X}^{2}$ test for homogeneity was used to determine whether there were significant proportional differences regarding the witnessing of, victimisation by and exposure to violence for the two ethnic groups. An analysis of variance was performed to determine whether any significant differences exist between the mean scores of the two ethnic groups on the PTSDC and CEVF scores. In order to determine the second aim of the study, namely whether there was a positive relationship between the participants' PTSDC scores and their exposure to violence, the Pearson product-moment correlation coefficient $(r)$ was computed. Fisher's $r$-to-Z $Z$ transformation was determined in order to establish whether the relationship between PTSD and exposure to violence differed for the two language groups. Finally, effect sizes were calculated so that it 
would be possible to comment on the practical importance of statistically significant results (Steyn, 1999:1). Effect sizes were only calculated where comparisons were statistically significant at the $5 \%$ level or higher.

\section{RESULTS}

Levels of self-reported exposure to different kinds of violence (being a witness to or victim of at least one violent incident), based on responses to the CEVF, are presented in Table 1.

The exposure to violence is high for both groups. From Table 1 , it is evident that more than $50 \%$ of the total group have seen somebody being beaten up, while $43.3 \%$ of them have been threatened in this regard. When considering the two ethnic groups, it can be seen that the following three violent acts (in order of exposure) have been witnessed among the Northern Sotho adolescents: knife-pulling (51.0\%); somebody being beaten up (47.7\%); and somebody being shot (43.0\%).
Regarding victimisation, the two violent acts to which these adolescents have received the highest degree of exposure are: being threatened with a beating (35.1\%) and being beaten up (31.8\%). The following three violent acts (in order of exposure) were witnessed by the Venda adolescents: somebody being beaten up (61.3\%); knife-pulling (43.0\%); and somebody being stabbed (37.6\%). Regarding victimization, the two most prevalent violent acts to which the adolescents have been exposed are the same as for the Northern Sotho group, namely: being threatened with a beating (50.0\%) and being beaten up (43.5\%).

Table 2 shows the percentage of participants in each ethnic group who had witnessed at least one violent act, who had been victims of at least one violent act, and who had been exposed (as witnesses or victims) to at least one violent act. At least one violent act had been witnessed by $93.0 \%$ of the Venda adolescents, while $77.4 \%$ had been victims of violence and $96.8 \%$ had been exposed to an act of violence. In compari-

Table 1: Percentage of participants reporting exposure to different kinds of violence on the CEVF

\begin{tabular}{|l|l|l|l|l|l|l|}
\hline Exposure to violence & \multicolumn{3}{l}{ Northern Sotho } & \multicolumn{2}{l|}{ Venda } & \multicolumn{2}{l|}{ Total group } \\
\hline Witnessed & $\mathbf{N}$ & $\mathbf{9}$ & $\mathbf{N}$ & $\%$ & $\mathbf{N}$ & $\%$ \\
\hline Beating & 72 & 47.7 & 114 & $\mathbf{6 1 . 3}$ & 186 & $\mathbf{5 5 . 2}$ \\
\hline Stabbing & 41 & 27.2 & 70 & 37.6 & 111 & 32.9 \\
\hline Shooting & 65 & 43.0 & 58 & 31.2 & 123 & 36.5 \\
\hline Home violence & 53 & 35.1 & 69 & 37.1 & 122 & 36.2 \\
\hline Dead body & 31 & 20.5 & 52 & 28.0 & 83 & 24.6 \\
\hline Gun pulled & 49 & 32.5 & 48 & 25.8 & 97 & 28.9 \\
\hline Home shooting/stabbing & 38 & 25.2 & 37 & 19.9 & 75 & 22.3 \\
\hline Knife pulled & 77 & $\mathbf{5 1 . 0}$ & 80 & 43.0 & 157 & 46.6 \\
\hline Murder & 53 & 35.1 & 51 & 27.4 & 104 & 30.9 \\
\hline Suicide & 55 & 36.4 & 66 & 35.5 & 121 & 35.9 \\
\hline Sexual assault & 50 & 33.1 & 55 & 29.6 & 105 & 31.2 \\
\hline Riot & 47 & 31.1 & 53 & 28.5 & 100 & 29.7 \\
\hline Victimisation & & & & & & \\
\hline Robbed & 35 & 23.2 & 40 & 21.5 & 75 & 22.3 \\
\hline Threatened (beaten up) & 53 & $\mathbf{3 5 . 1}$ & 93 & $\mathbf{5 0 . 0}$ & 146 & $\mathbf{4 3 . 3}$ \\
\hline Beaten up & 48 & 31.8 & 81 & 43.5 & 129 & 38.3 \\
\hline Threatened with death & 32 & 21.2 & 44 & 23.7 & 76 & 22.6 \\
\hline
\end{tabular}

Note: Highest percentages for witnessed violence and victimisation are in bold 
Table 2: Frequencies and percentages of participants reporting witnessing violence, being a victim of violence and any exposure to violence with associated values of $\mathrm{X}^{2}$

\begin{tabular}{|l|l|l|l|l|}
\hline \multirow{2}{*}{ Violence } & \multicolumn{2}{|l|}{ Northern Sotho } & \multicolumn{2}{l|}{ Venda } \\
\cline { 2 - 5 } & $\mathbf{N}$ & $\%$ & $\mathbf{N}$ & $\%$ \\
\hline $\begin{array}{l}\text { Witnessed at least one act of } \\
\text { violence }\end{array}$ & 136 & 90.1 & 173 & 93.0 \\
\hline $\begin{array}{l}\text { Victim of at least one act of } \\
\text { violence }\end{array}$ & 93 & 61.6 & 144 & 77.4 \\
\hline $\begin{array}{l}\text { Exposed to at least one act of } \\
\text { violence }\end{array}$ & 140 & 92.7 & 180 & 96.8 \\
\hline \begin{tabular}{l}
$X^{2}=1.519$ (degrees of freedom $\left.=2\right) ; p=0.4679$ \\
\hline
\end{tabular}
\end{tabular}

son, the corresponding percentages for the Northern Sotho adolescents were $90.1 \%, 61.6 \%$ and $92.7 \%$ respectively. These percentages were slightly lower than for the Venda group. To determine whether there were significant proportional differences between the two ethnic groups regarding witnessing of, victimisation by and exposure to violence, the $\mathrm{X}^{2}$ test for homogeneity was used; these results are presented at the bottom of Table 2. No significant proportional differences were found.

On the PTSDC, almost half the participants' reported symptoms consistent with a diagnosis of PTSD, although - as already mentioned - a conclusive diagnosis cannot be made on the basis of a self-report scale. Sixty-nine $(45.7 \%)$ of the 151 Northern Sotho adolescents and $75(40.3 \%)$ of the 186 Venda adolescents reported significant PTSD symptoms. There were no significant proportional differences between the two ethnic groups $\left(X^{2}=0.1604 ; p=0.69\right)$. This finding corresponds with the findings of other South African and international studies (Mazza \& Reynolds, 1999:207; Pynoos et al. 1987:1057; Seedat et al. 2004:172; Singer et al. 1995:477). The percentage of participants with scores consistent with PTSD is higher than the percentages found in other South African and international studies (Peltzer, 1999:646). A notable exception is a study by Myers and Thompson (2000:261) that focused on African-American youths in the USA, where a similar finding was made: on the basis of the Posttraumatic Stress Disorder Reaction Index (CPTSD-RI), $49.1 \%$ of the adolescents were diagnosed with PTSD.

An analysis of variance was performed to determine whether ethnicity had any significant effect on CEVF and PTSDC full-scale and subscale scores. The results are displayed in Table 3.

A statistically significant difference (on the $1 \%$ level) was found for the dependent variable "victim of a violent act(s)": Venda participants reported a higher incidence of being a victim of violence than Northern Sotho participants. The corresponding effect size indicates that the result is of medium to high practical value. No significant differences were found for the remaining dependent variables.

Pearson product moment correlations for the full sample were calculated between PTSDC full-scale and subscale scores on the one hand, and the full-scale and subscale scores of the CEVF on the other. They were also calculated separately for the two ethnic groups. These values are displayed in Table 4.

Fisher's $r$-to- $Z$ transformation was used to determine whether any differences existed between these relationships for the two ethnic groups. In the case of the CEVF full scale (total exposure), significant relationships were found with each of the PTSDC subscales, as well as with the PTSDC full scale. These relationships were found in the total group, as well as in each ethnic group separately. All of these correlation coefficients were statistically significant, and were associated with medium to large effect sizes. The strength of the correlations between the CEVF full scale and the PTSDC full scale, as well as between the CEVF full scale and Cluster B (Re-experiencing) and the CEVF 
Table 3: Means, standard deviations and summary of analysis of variance of CEVF and PTSDC full scale and subscale scores

\begin{tabular}{|c|c|c|c|c|c|c|c|}
\hline \multirow[t]{2}{*}{ Scales } & \multicolumn{2}{|c|}{ Northern Sotho } & \multicolumn{2}{|c|}{ Venda } & \multirow[t]{2}{*}{$\boldsymbol{F}$} & \multirow[t]{2}{*}{$p$} & \multirow[t]{2}{*}{$f$} \\
\hline & $\overline{\bar{X}}$ & SD & $\overline{\bar{X}}$ & SD & & & \\
\hline CEVF: Witness & 6.51 & 4.83 & 6.42 & 3.76 & 0.13 & 0.7161 & \\
\hline CEVF: Victim & 1.55 & 1.93 & 2.30 & 2.24 & $7.75^{\star *}$ & 0.0057 & 0.36 \\
\hline CEVF: Total & 16.96 & 11.95 & 18.05 & 9.74 & 0.01 & 0.9961 & \\
\hline $\begin{array}{l}\text { PTSDC - B Re- } \\
\text { experiencing }\end{array}$ & 8.76 & 5.16 & 9.13 & 4.30 & 0.17 & 0.6803 & \\
\hline PTSDC - C Avoidance & 10.47 & 5.43 & 11.62 & 4.54 & 0.50 & 0.4801 & \\
\hline PTSDC - D Hyperarousal & 6.26 & 3.68 & 6.32 & 3.46 & 0.01 & 0.9187 & \\
\hline PTSDC Total & 25.49 & 12.57 & 27.06 & 10.39 & 0.26 & 0.6104 & \\
\hline
\end{tabular}

${ }^{*} p \leq 0.05 ;{ }^{* *} p \leq 0.01$

Table 4: Correlations between PTSDC full scale and subscales and CEVF full scale and subscales for the total sample as well as the separate language groups

\begin{tabular}{|c|c|c|c|c|c|c|c|c|c|c|c|c|}
\hline \multirow{2}{*}{$\begin{array}{l}\text { PTSDC } \\
\text { scales }\end{array}$} & \multicolumn{4}{|c|}{ CEVF Witnessed violence } & \multicolumn{4}{|c|}{ CEVF Victimisation } & \multicolumn{4}{|c|}{ CEVF Exposure (total) } \\
\hline & $\begin{array}{l}\text { Total } \\
\text { group }\end{array}$ & $\begin{array}{l}N . \\
\text { Sotho }\end{array}$ & Venda & $z$ & $\begin{array}{l}\text { Total } \\
\text { group }\end{array}$ & \begin{tabular}{|l}
$N$. \\
Sotho
\end{tabular} & Venda & $z$ & $\begin{array}{l}\text { Total } \\
\text { group }\end{array}$ & \begin{tabular}{|l|}
$N$ \\
Sotho
\end{tabular} & Venda & $z$ \\
\hline $\begin{array}{l}\text { PTSDC - } \\
\text { Cluster B } \\
\text { Re- } \\
\text { experiencing }\end{array}$ & $0.39^{\star \star}$ & $0.45^{\star \star}$ & $0.33^{\star \star}$ & 1.30 & $0.20^{\star \star}$ & $0.28^{\star \star}$ & $0.15^{\star}$ & 1.26 & $0.47^{\star \star}$ & $0.56^{\star \star}$ & $0.39^{\star \star}$ & $2.00^{\star}$ \\
\hline $\begin{array}{l}\text { PTSDC - } \\
\text { Cluster C } \\
\text { Avoidance }\end{array}$ & $0.29^{\star \star}$ & $0.44^{\star \star}$ & 0.14 & $\begin{array}{l}3.04^{*} \\
*\end{array}$ & $0.14^{*}$ & $0.21^{\star \star}$ & 0.09 & 1.13 & $0.30^{\star \star}$ & $0.44^{\star \star}$ & $0.16^{*}$ & $\begin{array}{l}2.81^{\star} \\
\star\end{array}$ \\
\hline $\begin{array}{l}\text { PTSDC - } \\
\text { Cluster D } \\
\text { Hyperarousal }\end{array}$ & $0.29^{\star \star}$ & $0.36^{\star \star}$ & $0.24^{\star \star}$ & 1.21 & $0.13^{*}$ & $0.22^{\star \star}$ & 0.08 & 1.32 & $0.31^{\star \star}$ & $0.41^{\star \star}$ & $0.22^{\star \star}$ & 1.92 \\
\hline $\begin{array}{l}\text { PTSDC - } \\
\text { Total }\end{array}$ & $0.38^{\star \star}$ & $0.48^{\star *}$ & $0.28^{\star \star}$ & $2.16^{*}$ & $0.19^{\star \star}$ & $0.27^{\star \star}$ & 0.13 & 1.34 & $0.42^{\star \star}$ & $0.54^{\star \star}$ & $0.31^{* \star}$ & $2.56^{\star}$ \\
\hline
\end{tabular}

full scale Cluster C (Avoidance) subscales, was significantly greater for the Northern Sotho group than for the Venda group.

There was a similar pattern of findings with regard to the CEVF witnessing subscale that correlated significantly with each of the subscales and the full scale of the PTSDC for the total group, as well as for the Northern Sotho group alone; in the case of the Venda group, the correlation with PTSDC Cluster C (Avoidance) was not significant. The strength of the relationship between witnessing and PTSD was significantly higher for the Northern Sotho participants than for the Venda participants in the case of PTSD Cluster C (Avoidance) and 
the PTSDC full scale. A similar pattern of results was obtained with the CEVF victimisation subscale, where significant correlations occurred with each of the subscales and the full scale of the PTSDC for the total group. These correlations were lower than those obtained with the CEVF witnessing subscale; they were particularly low among the Venda participants, where most of the correlations did not attain statistical significance (except PTSDC Cluster B). However, none of the differences between the language groups were statistically significant.

\section{DISCUSSION}

Perhaps the most striking feature of the present findings is that almost half of the participants reported marked PTSD symptoms. In addition, the positive correlations obtained between the results of the PTSDC and CEVF scores provide further evidence supporting the view that a person's chances of developing PTSD are directly linked to the level of exposure to violence. This is in line with other findings - both internationally and in South Africa - in respect of being a direct victim of violence (Myers \& Thompson, 2000:264; Singer et al. 1995:477), as well as witnessing violence (Fitzpatrick \& Boldizar, 1993:424; Peltzer, 2003:24; Pynoos et al. 1987:1057; Singer et al. 1995:477). Although the correlations in Table 4 concerning witnessed violence were higher than those concerning being a direct victim of violence, this cannot be interpreted to imply that there is a stronger relationship between witnessing violence and PTSD than between being a victim and PTSD. This can be ascribed to the fact that our analyses are not based on comparisons of two pure groups, as many participants who reported witnessing violence also reported that they had been victims. Nevertheless, it is perhaps surprising that the correlations with witnessing violence were higher than the correlations with being a victim of violence.

Furthermore, there are no clear differences between the two ethnic groups in terms of the extent of PTSD symptoms or overall exposure to violence, except that there was a tendency for the Venda participants to report a higher exposure to victimisation than the Northern Sotho adolescents. The correlation between CEVF and PTSDC scores was stronger in the Northern Sotho group than among the Venda adolescents, although this finding is difficult to interpret. However, other re- search findings in this regard are contradictory (Perilla et al. 2002:20). It therefore seems that more research in this area should be undertaken.

There are several aspects of the findings that could have an effect on the reliability of the results. The alpha coefficient for the PTSDC full scale was very satisfactory, but those for the PTSDC subscales were rather low. Language is one aspect that may have contributed to this. Several authors, such as Edwards and Moldan (2004:201), emphasise that - even though participants who use English as their second language may be fluent in English - they may still misunderstand certain items in a questionnaire, and this can lower the internal consistency of scales. These authors also hypothesise that the higher the level of incomprehension regarding test items among participants, the less likely they will be to take the test situation seriously. The CEVF was altered for the study, and certain questions were eliminated in the comparison of witnessed and victimisation events to PTSD symptomatology. The addition of new questions to the form with regard to riot-related experiences, as well as the elimination of other questions, may have affected the test's reliability. This also means that our scores cannot be compared directly to those of other studies in which the CEVF was used. It is recommended that, for future studies, the subcategories of experiences of violence should be carefully refined.

There are several factors that limit the generalisability of the findings. First of all, the age span of the participants in the study only encompassed middle and late adolescence. We do not know to what extent the same findings would have been obtained with younger adolescents. Secondly, the study took place in two remote rural areas of the Limpopo Province. High levels of exposure to violence have been reported in rural areas of KwaZulu-Natal, as well as urban areas in KwaZulu-Natal and the Western Cape. However, there may be areas with much lower levels of exposure to violence, where considerably lower levels of PTSD symptomatology might be found. Thirdly, the two groups of participants in the study comprised relatively homogeneous populations from two specific geographical areas. As a result of this variable and also the way in which the samples were selected, caution must be exercised when comparing this sample with other Venda and Northern Sotho groups. This also applies to a com- 
parison with more ethnically diverse populations, or with other homogeneous language-group populations in South Africa. Fourthly, it should be taken into account that the information used in the study was obtained exclusively by means of self-report data, which may not be entirely accurate owing to the possibility of selfreport bias.

Despite these limitations, the results strongly suggest that adequate funding is needed to provide mental health care resources to adolescents in the rural areas, such as the area in which this study was conducted. Greater awareness must be cultivated among community leaders, local healers, teachers, parents, the government, health care workers and children concerning the damaging effects of exposure to violence in relation to the potential development of a mental illness such as PTSD. Mental health problems can adversely affect an individual's functioning, both socially and academically, and the quality of life of many rural South African adolescents could be improved considerably by concerted efforts directed towards the prevention of and protection against violence, as well as the detection and treatment of PTSD.

\section{REFERENCES}

AMAYA-JACKSON, L 1995: Child's Exposure to Violence Form. Durham, NC: Center for Child and Family Health, Duke University. AMAYA-JACKSON, L; MCCARTHY, L; NEWMAN, E \& CHERNEY, M 1995: Child PTSD Checklist, Trauma Evaluation, Treatment and Research Program. Durham, NC: Center for Child and Family Health, Duke University.

AMERICAN PSYCHIATRIC ASSOCIATION (APA) 2000: Diagnostic and statistical manual of mental disorders. TR; $4^{\text {th }}$ edition, text revision. Washington, DC: APA.

BAKER, AM 1991: Psychological response of Palestinian children to environmental stress associated with military occupation. Journal of Refugee Studies, 4(3):237-247.

BERTON, MW \& STABB, SD 1996: Exposure to violence and posttraumatic stress disorder in urban adolescents. Adolescence, 31(122):489-498.

BLIGNAUT, SCW 1996: Post-traumatic stress disorder: An epidemiological study in the Rocklands community. Bloemfontein: University of the Orange Free State (Unpublished master's thesis). CHIH-HAO, K \& JING-HOUNG, K 1997: A study of adolescent life stress, intervention of welfare services and psychological wellbeing for single-parent families in Taipei municipal city. Journal of Education and Psychology, 20(2):243-270.
COOLEY-QUILLE, MR; TURNER, SM \& BEIDEL, DC 1995: Emotional impact of children's exposure to community violence: A preliminary study. Journal of the American Academy of Child and Adolescent Psychiatry, 34(10):1362-1368.

COOLEY-QUILLE, M; BOYD, RC; FRANTZ, E \& WALSCH, J 2001: Emotional and behavioural impact of exposure to community violence in inner-city adolescents. Journal of Clinical Child Psychology, 30(2):199-206.

CROUCH, J; HANSON, R; SAUNDERS, B; KILPATRICK, D \& RESNICK, H 2000: Income, Race/Ethnicity, and exposure to violence in youth: Results from the national survey of adolescents. Journal of Community Psychology, 28(6):625-641.

DUCKWORTH, MP; HALE, DD; CLAIR, SD \& ADAMS, HE 2000: Influence of interpersonal violence and community chaos on stress reactions in children. Journal of Interpersonal Violence, 15(8):806-826.

EDWARDS, D 2005: Post-traumatic stress disorder as a public health concern in South Africa. Journal of Psychology in Africa, 15(2):125-134.

EDWARDS, D \& MOLDAN, S 2004: Bulimic pathology in Black students in South Africa: Some unexpected findings. South African Journal of Psychology, 34(2):191-205.

ENSINK, K; ROBERTSON, AB; ZISSIS, C \& LEGER, P 1997: Posttraumatic stress disorder in children exposed to violence. South African Medical Journal, 87(11):1526-1530.

FEHON, D; GRILO, C \& LIPSCHITZ, D 2001: Gender differences in violence exposure and violence risk among adolescent inpatients. Journal of Nervous and Mental Disease, 189(8):532-540. FITZPATRICK, KM 1993: Exposure to violence and presence of depression among low-income, African-American youth. Journal of Consulting and Clinical Psychology, 61(3):528-531.

FITZPATRICK, KM \& BOLDIZAR, JP 1993: The prevalence and consequences of exposure to violence among African-American youth. Journal of the American Academy of Child and Adolescent Psychiatry, 32(2):424-430.

FOSTER, J \& PARKER, I 1995. Carrying out investigations in Psychology: Methods and statistics. Leicester: The British Psychological Society.

GIACONIA, RM; REINHERZ, HZ; SILVERMAN, AB; PAKIZ, B; FROST, AK \& COHEN, E 1995: Traumas and Posttraumatic stress disorder in a community population of older adolescents. Journal of the American Academy of Child and Adolescent Psychiatry, 34(10):1369-1380.

HUNT, S 2003: Turning the tide of violence in South Africa. International Development Research Centre. Available from: http:/ /www.idrc.ca/en/ev-45629-201-1-DO_TOPIC.HTML (Accessed: 24 January 2007).

LIPSCHITZ, D; GRILO, C; FEHON, D; MCGLASHAN, T \& SOUTHWICK, $S$ 2000: Gender differences in the associations between 
posttraumatic stress symptoms and problematic substance use in psychiatric inpatient adolescents. Journal of Nervous and Mental Disease, 188(6):349-356.

LITROWNIK, AJ; NEWTON, RAE; HUNTER, WM; ENGLISH, D \& EVERSON, MD 2003: Exposure to family violence in young at-risk children: A longitudinal look at the effects of victimization and witnessed physical and psychological aggression. Journal of Family Violence, 18(1):59-73.

MASUKU, S 2002: Prevention is better than cure. Addressing violent crime in South Africa. SA Crime Quarterly, 3(2):5-12. MAZZA, JJ \& REYNOLDS, WM 1999: Exposure to violence in younger inner-city adolescents: Relationships with suicidal ideation, depression, and PTSD symptomatology. Journal of Abnormal Child Psychology, 27(3):203-213.

MGHIR, R \& RASKIN, A 1999: The psychological effects of the war in Afghanistan on young Afghan refugees from different ethnic backgrounds. International Journal of Social Psychiatry, 45(1):29-40.

MYERS, MA \& THOMPSON, VL 2000: The impact of violence exposure on African American youth in context. Youth \& Society, 32(2):253-267.

NATIONAL CENTER FOR JUVENILE JUSTICE 1999: Juvenile offenders and victims: 1999 National report. Available from National Criminal Justice Reference Title Web site: http://www.ncjrs.org/ html/ojjdp/nationalreport99/toc.html (Accessed 10 March 2005). NEAL, A \& TURNER, S 1991: Anxiety disorders research with African Americans: Current status. Psychological Bulletin, 109(3):400-410.

PELCOVITZ, D; KAPLAN, SJ; DE ROSE, RR; MANDEL, FS \& SALZINGER, S 2001: Psychiatric disorders in adolescents exposed to domestic violence and physical abuse. American Journal of Orthopsychiatry, 70(3):360-368.

PELTZER, K 1999: Posttraumatic stress symptoms in a population of rural children in South Africa. Psychological Reports, 85(2):646-650.

PELTZER, K 2003: Prevalence of traumatic events and post-traumatic stress symptoms among taxi drivers and passengers in South Africa. Acta Criminologica, 16(1):21-26.

PERILLA, J; NORRIS, F \& LAVIZZO, E 2002: Ethnicity, culture, and disaster response: Identifying and explaining ethnic differences in PTSD six months after Hurricane Andrew. Journal of Social and Clinical Psychology, 21(1):20-45.

POELMANS, S 2001: Work-family conflict as a mediator of the work stress - mental health relationship. Available from http:// netec.mcc.ac.uk/WoPEc/data/Papers?epgiesewpd-0443.html (Accessed: 17 September 2003).

PYNOOS, R; FREDERICK, C; NADER, K; ARROYO, W; ETH, S; NUNEZ, W; STEINBERT, A \& FAIRBANKS, L 1987: Life threat and posttraumatic stress in school age children. Archives of Gen- eral Psychiatry, 44(2):1057-1063

SAIGH, PA 1991: The development of posttraumatic stress disorder following four different types of traumatization. Behaviour Research and Therapy, 29(3):213-216.

SEEDAT, S; VAN NOORD, E; VYTHILINGUM, B; STEIN, DJ \& KAMINER, D 2000: School survey of exposure to violence and posttraumatic stress symptoms in adolescents. South African Journal of Child and Adolescent Mental Health, 12(1):3844.

SEEDAT, S; NYAMAI, C; NJENGA, F; VYTHILINGUM, B \& STEIN, DJ 2004: Trauma exposure and posttraumatic stress symptoms in adolescents: A schools survey in Cape Town and Nairobi. British Journal of Psychiatry, 184(2):169-175.

SHANNON, MP; LONIGAN, J; FINCH, A \& TAYLOR, CM 1994: Children exposed to disaster: I. Epidemiology of post-traumatic symptoms and symptom profiles. Journal of the American Academy of Child and Adolescent Psychiatry, 33(1):80-93.

SINGER, MI; ANGLIN, TM; SONG, LY \& LUNGHOFER, L 1995: Adolescents' exposure to violence and associated symptoms of psychological trauma. Journal of the American Medical Association, 273(6):477-482.

SLOVAK, K \& SINGER, M 2001: Gun violence exposure and trauma among rural youth. Violence and Victims, 16(4):389-400.

STEYN, HS 1999: Praktiese beduidendheid: Die gebruik van effekgroottes. Potchefstroom: Publikasiebeheerkomitee, PU vir $\mathrm{CHO}$. 